\title{
Effect of Source of Heat and Storage Period on Physicochemical and Microbiological Characteristics of Goat Milk
}

Mohamed Osman Mohamed Abdalla ${ }^{1 *}$, Zubida Elsayed Abdalla Elsayed ${ }^{1}$, Abdelazim Ahmed Mohamed Nour ${ }^{2}$

${ }^{1}$ Department of Dairy Production, Faculty of Animal Production, University of Khartoum, Sudan.

${ }^{2}$ Department of Food Science and Technology, Faculty of Agriculture, University of Khartoum, Sudan.

\begin{abstract}
This investigation was conducted to evaluate the effect of heat treatment of goat milk with charcoal, gas and microwave on the physicochemical and microbiological characteristics during the storage period. Raw goat milk was heated with charcoal, gas and microwave at $99^{\circ} \mathrm{C}$ for $12 \mathrm{~min}$ followed by storage at $4^{\circ} \mathrm{C}$ for 10 days. Physicochemical and microbiological characteristics were determined at 1,3,7 and 10-day intervals. The results showed a significant effect of source of heat on the physicochemical characteristics under study except fat content and $\mathrm{pH}$. The highest protein $(3.62 \%)$, lactose $(4.97 \%)$ and solids-non-fat (SNF) $(9.31 \%)$ contents were high in milk heated with charcoal, while fat $(5.68 \%)$ and total solids (TS) $(14.26 \%)$ contents were high in milk treated with microwave and the acidity $(0.19 \%)$ was high in milk treated with gas. The total viable bacteria (TVB) and lactic acid bacteria (LAB) were significantly $(\mathrm{P}<0.001)$ higher $(\log 2.31 \mathrm{cfu} / \mathrm{ml}$ and $\log$ $2.26 \mathrm{cfu} / \mathrm{ml}$, respectively) in milk heated with charcoal. The protein, TS, lactose, SNF and acidity increased during the storage period, while fat and ash decreased. TVB and LAB increased during the storage period. Bacillus and Staphylococcus genera survived the heat treatment and were isolated in heated milk till day 7 of the storage period, and then Staphylococcus was not detected at day 10.
\end{abstract}

Keywords: Goat milk, Heat, Microbiological, Physicochemical, Storage priod.

\section{*Corresponding Author:}

Mohamed Osman Mohamed Abdalla,

Department of Dairy Production, Faculty of Animal Production, University of Khartoum, Shambat, P.O. Box 32, Postal Code 13314, Khartoum North, Sudan.

E-mail: abutahany@yahoo.com

Received: April 15, 2015

Accepted: May 05, 2015

Published: May 07, 2015

Citation: Mohamed Osman Mohamed Abdalla, Zubida Elsayed Abdalla Elsayed, Abdelazim Ahmed Mohamed Nour (2015) Effect of Source of Heat and Storage Period on Physicochemical and Microbiological Characteristics of Goat Milk. Int J Dairy Process Res. 2(4), 18-23.

doi: http://dx.doi.org/10.19070/2379-1578-150007

Copyright: Mohamed Osman Mohamed Abdalla ${ }^{\odot}$ 2015. This is an open-access article distributed under the terms of the Creative Commons Attribution License, which permits unrestricted use, distribution and reproduction in any medium, provided the original author and source are credited.

\section{Introduction}

Goat milk and their products are nutritionally versatile having gained a wide demand due to their potential nutraceutical properties. Goat milk can get contaminated by various pathogenic or spoilage microorganisms (mainly bacteria) during various stages of processing and storage from farm to table. Presence of high microbial load in milk can pose major economical loss for local farmers and small hold dairies, as milk price is calculated based on the bacteria count [1]. Goat milk is more sensitive to high heat treatments than bovine milk. The $\mathrm{pH}$, micelle hydration, genetic polymorphism of $\alpha-\mathrm{S} 1$ casein, non-protein nitrogen, salt balance and ionic calcium could be directly or indirectly involved in the heat sensitivity of milk [2]. Goats play a significant role in the food chain and overall livelihood of rural households, where they are largely the property of women and their children. These animals can be reared for various reasons such as income generation, religious purposes, household consumption and as security against crop failure [3]. The main objective of milk heat treatment is to eliminate pathogenic microorganisms, or reduce them to a level safe for human consumption and to increase the shelf-life by inactivating spoilage microorganisms without affecting the nutritive value of milk [4].

When milk is heated some changes such as appearance of scum take place on the surface, with prolonged heating complete coagulation of milk takes place, and on continuous heating some proteins form a flocculent precipitate which collects on the bottom of the pan and causes scorching [4]. On heating milk for extended period of time, it is subjected to browning reaction caused by the union of free amino groups with milk reducing sugar [5]. In modern dairy industry, milk heat treatment is the major method for milk preservation and extending the shelf life [4]. Heat treatment methods include thermization, low temperature long time, high temperature short time, sterilization and ultra high temperature [6]; however, in many rural areas traditional methods such as boiling are the methods of choice. Recently, many methods other than heat treatment were used to improve the quality of fresh milk including ultraviolet treatment [7,8], microwave [9] and gas [4]. The quality of most dairy products is closely related to the microbial status of raw milk from which they are manufactured. 
Managing the safety of milk involves controlling the various endogenous and exogenous sources of contamination. Diseases such as salmonellosis, tuberculosis, brucellosis, listeriosis, Q fever, toxoplasmosis, streptococcal and staphylococcal infections and campylobacter infections can be transmitted to humans from milk. Endogenous contamination of mastitic agents in goats include coagulase-negative staphylococcus species; Staphylococcus aureus and streptococcus species [10]. Depending on the temperature, conditions and length of milk storage, various groups of microorganisms can undergo a period of intensive growth producing high concentrations of enzymes, particularly lipases and proteinases. Although the microorganisms are destroyed by sterilization, the enzymes produced may remain active in sterilized products [11].

The heat stability of milk is reduced when it is first homogenized and then heated, but not when homogenization follows heating [12]. The reason for this seems to be that heat-induced interactions of serum protein with fat surface-adsorbed casein promote heat coagulation. In Sudan, the major milk heat treatment method is the boiling by charcoal in the rural areas and gas in the urban areas. However, recently some methods have been tried utilizing the solar energy for milk heating [4]. In addition, microwave technology is recently being introduced into Sudan as a method of heat treatment. Therefore, this study is conducted to assess the effect of different heat treatment and storage periods on the physicochemical and microbial characteristics of goat milk.

\section{Materials and Methods}

\section{Source of milk}

Fresh raw goat milk was obtained from a dairy farm in Shambat area, Khartoum North.

\section{Sampling of milk}

Milk samples were aseptically transferred into sterile glass bottles and transported to the laboratory inside ice box $\left(\leq 4^{\circ} \mathrm{C}\right)$. During analysis the samples were first aseptically drawn for microbiological examination, and then samples for chemical analysis were drawn. The samples were heat-treated immediately on arrival to the laboratory.

\section{Method of heat treatment}

Milk was heat-treated by charcoal, gas and microwave at $99^{\circ} \mathrm{C}$ and held on this temperature during $12 \mathrm{~min}$. The milk was then cooled to $4^{\circ} \mathrm{C}$ and stored for 10 days. Physicochemical and microbiological characteristics of milk were determined for raw milk and milk heat-treated at 1, 3, 7 and 10 day-intervals.

\section{Determination of chemical composition of milk}

Chemical analyses (fat, protein, SNF and density) of milk samples were determined by using Lactoscan 90 milk analyzer (Aple Industries Service-La Roche Sur Foron, France). Milk samples were mixed gently 4-5 times to avoid any air enclosure in the milk, then $5 \mathrm{ml}$ of the sample were taken in the sample-holder, one at a time and put in the sample holder with the analyzer in the recess position. The starting button was inactivated, the analyzer sucked the milk, the measurements were taken and the results were shown on the digital display. Before used Lactoscan, it was calibrated in accordance with the standard method.

\section{Determination of ash content, titrable acidity and $\mathrm{pH}$}

The ash content and titrable acidity were determined according to AOAC [13] and pH meter (Hanna-instrument model 98107, Mauritium) were used for determining $\mathrm{pH}$. Before determination, $\mathrm{pH}$ meter was calibrated by using buffer solutions No. 4 and 7 .

\section{Microbiological examination}

Preparation of sample dilutions: Ten millilitres of the sample were added to $90 \mathrm{ml}$ of sterile $0.1 \%$ peptone water at $45^{\circ} \mathrm{C}$ in a clean sterile flask, then shacked until a homogenous solution was obtained to make $10^{-1}$ dilution. One $\mathrm{ml}$ from the above-mentioned dilution $\left(10^{-1}\right)$ was aseptically transferred to $9 \mathrm{ml}$ sterile distilled water. This procedure was repeated to make serial dilutions of $10^{-2}-10^{-8}$.

Total viable bacteria count: The total viable bacteria count was determined according to Houghtby et al. [14] using standard plate count agar. The plates were incubated at $32^{\circ} \mathrm{C}$ for $48 \mathrm{hrs}$ and colonies were counted.

Lactic acid bacteria count: The lactic acid bacteria count was determined according to Harrigan [15]. The appropriate sample dilution $(0.1 \mathrm{ml})$ was aseptically transferred to pre-solidified M17 agar medium, spread plated and incubated at $37^{\circ} \mathrm{C}$ for $72 \mathrm{hr}$ under anaerobic conditions using anaerobic jar, and the typical colonies were counted.

Identification of bacteria (biochemical tests): The following primary tests were used to identify bacterial isolates to the genus level [16] Gram stain, catalase test, oxidase test, motility test, oxidation fermentation test $(\mathrm{O} / \mathrm{F})$ and endospore staining test.

\section{Statistical analysis}

The data were analyzed using Statistical Analysis Systems (SAS, ver. 9). General Linear Models (GLM) was used to study the effect of source of heat and storage period on the chemical composition and microbiological quality of milk. Means were separated by Duncan multiple range test ( $\mathrm{P} \leq 0.05)$.

\section{Results and Discussions}

\section{Physicochemical and microbiological characteristics of goat milk heated with different sources of heat}

The physicochemical and microbioligical characteristics of raw goat milk was as follows: fat $4.35 \%$, protein $3.53 \%$, TS $13.45 \%$, lactose $4.83 \%$, SNF $9.07 \%$, ash $0.65 \%$, titratable acidity $0.17 \%$, pH 6.19, TVB count $\log 7.69 \mathrm{cfu} / \mathrm{ml}$, lactic acid bacteria count $\log 6.51$ $\mathrm{cfu} / \mathrm{ml}$. Table 1 shows that fat content was significantly $(\mathrm{p}<0.001)$ higher when milk was heated by microwave (5.68\%), and lower when milk was heated by gas $(3.41 \%)$. The protein content was found to be higher $(\mathrm{p}<0.05)$ in milk heated by charcoal $(3.62 \%)$, while TS content was higher $(\mathrm{p}<0.05)$ when milk was heated with microwave $(14.26 \%)$. Lactose $(\mathrm{p}<0.001)$ and SNF $(\mathrm{p}<0.001)$ contents were higher in milk heated with charcoal $(4.97 \%$ and $9.31 \%$ respectively), while acidity was higher $(\mathrm{p}<0.01)$ in milk heated by 
Table 1. Effect of source of heat on physicochemical and microbiological characteristics quality of goat milk heated by charcoal, gas and microwave.

\begin{tabular}{|c|c|c|c|c|c|}
\hline \multirow{2}{*}{ Parameter } & \multicolumn{3}{|c|}{ Source of heat } & \multirow{2}{*}{ SE } & \multirow{2}{*}{ SL } \\
\cline { 2 - 4 } & Charcoal & Gas & Microwave & & \\
\hline Fat $(\%)$ & $3.97^{\mathrm{b}}$ & $3.41^{\mathrm{c}}$ & $5.68^{\mathrm{a}}$ & 0.38 & $* * *$ \\
\hline Protein $(\%)$ & $3.62^{\mathrm{a}}$ & $3.41^{\mathrm{b}}$ & $3.54^{\mathrm{ab}}$ & 0.03 & $*$ \\
\hline Total Solids (\%) & $13.11^{\mathrm{b}}$ & $12.97^{\mathrm{b}}$ & $14.26^{\mathrm{a}}$ & 0.75 & $*$ \\
\hline Lactose (\%) & $4.97^{\mathrm{a}}$ & $4.76^{\mathrm{b}}$ & $4.66^{\mathrm{ab}}$ & 0.14 & $* * *$ \\
\hline Solids-non-fat (\%) & $9.31^{\mathrm{a}}$ & $8.88^{\mathrm{b}}$ & $9.02^{\mathrm{ab}}$ & 0.24 & $* *$ \\
\hline Ash (\%) & $0.47^{\mathrm{a}}$ & $0.45^{\mathrm{a}}$ & $0.49^{\mathrm{a}}$ & 0.02 & $\mathrm{NS}$ \\
\hline Titratable acidity (\% lactic acid) & $0.16^{\mathrm{b}}$ & $0.19^{\mathrm{a}}$ & $0.18^{\mathrm{a}}$ & 0.01 & $* *$ \\
\hline pH & $6.21^{\mathrm{a}}$ & $6.24^{\mathrm{a}}$ & $6.12^{\mathrm{a}}$ & 0.13 & $\mathrm{NS}$ \\
\hline Total bacterial count1 & $2.31^{\mathrm{a}}$ & $2.30^{\mathrm{a}}$ & $2.19^{\mathrm{b}}$ & 1.30 & $* * *$ \\
\hline Lactobacilli count1 & $2.26^{\mathrm{a}}$ & $2.24^{\mathrm{a}}$ & $2.21^{\mathrm{b}}$ & 1.39 & $* * *$ \\
\hline
\end{tabular}

Means in each row bearing similar superscripts are not significantly different $(\mathrm{P}>0.05)$

$*=\mathrm{P}<0.05$

$* *=\mathrm{P}<0.01$

$* * *=\mathrm{P}<0.001$

$\mathrm{NS}=$ Not significant

$\mathrm{SE}=$ Standard error of means

SL $=$ Significance level

${ }^{1} \mathrm{Log} \mathrm{cfu} / \mathrm{ml}$

gas and microwave ( 0.19 and $0.18 \%$ respectively). Although the ash content and $\mathrm{pH}$ of milk were not significantly affected by the source of heat, the ash content was high in milk heated by microwave $(0.49 \%)$, and the $\mathrm{pH}$ was high in milk heated with gas (6.24). Microbiological results of milk heated with the three sources of heat showed that microwave heat treatment had more lethal effect on total bacteria count resulting in reduction of the number to $\log$ $2.19 \mathrm{cfu} / \mathrm{ml}$ compared to gas $(\log 2.30 \mathrm{cfu} / \mathrm{ml})$ and charcoal $(\log$ $2.31 \mathrm{cfu} / \mathrm{ml})$. The same effect of heat was noticed in lactic acid bacteria count when microwave application lead to a slight reduction in the number of lactic bacteria to $\log 2.21 \mathrm{cfu} / \mathrm{ml}$ compared to $\log 2.24 \mathrm{cfu} / \mathrm{ml}$ for gas and $\log 2.26 \mathrm{cfu} / \mathrm{ml}$ for charcoal heat treatment. From the results it is obvious that microwave treatment caused increase in fat, TS and ash contents, while charcoal heat treatment resulted in increased protein, lactose and SNF contents, and gas heat treatment resulted in increased acidity of milk. The results are in accordance with the findings of Bora and Goyal [17] who reported high fat and TS contents of milk heated by microwave and in disagreement with the finding of Sahan et al. [18] who reported no significant effect of pasteurization on the fat and protein contents of milk. However, these results contradict those reported by Abdalla and Daffalla [4] who reported high fat, TS and ash contents of milk heated with gas compared to charcoal and solar energy, while protein content was high when milk was heated with solar energy. Although time/temperature combination of heat treatment was similar to that used by Abdalla and Daffalla [4], gas treatment reduced protein content more. Hassan [19] reported that UHT resulted in a decreased fat, protein and TS contents of milk compared to low heat treatment $\left(85^{\circ} \mathrm{C} / 40 \mathrm{~min}\right)$ Matak et al. [8] reported that there is no significant change in fatty acid profile of goat milk treated with UV light. The results of microbiological examination indicate that microwave treatment had more detrimental effect on total viable bacteria (TVB) and lactic acid bacteria counts. These results are in line with the findings of Abdalla and Daffalla [4] who reported high TBC in conventional method (charcoal) compared to gas and solar energy, and
Clare et al. [9] who reported that UHT and microwave processing eliminated all bacterial growth in the milk as evidenced by the lack of colony formation using various microbiological media. The results of TVB count in this investigation are lower than those reported by Elzubeir et al. [20] who reported a mean TBC of log $5.99 \pm 4.47 \mathrm{cfu} / \mathrm{ml}$ for pasteurized milk, and Aggad et al. [21] who reported a mean aerobic mesophilic flora of $\log 5.21 \pm 5.19 \mathrm{cfu} /$ $\mathrm{ml}$ for pasteurized milk.

Effect of storage period on the quality of goat milk heated with charcoal, gas and microwave

Table 2 presents the effect of storage period on the chemical composition and microbiological characteristics of goat milk which was heated by charcoal, gas and microwave. In this research, fat content and $\mathrm{pH}$ for 1 and 10 day storage period were found to be $5.92 \%, 6.69$ and $4.70 \%, 6.04$ respectively. Fat content and $\mathrm{pH}$ values were decreased for 10 days period. In addition, protein, TS, lactose, SNF and ash contents steadily were increased as the storage period progressed $(1,3,7,10$ days).

However, the acidity fluctuated being high $(0.23 \%)$ at day 1 , then decreased at day $3(0.21 \%)$ before gradually increasing to $0.24 \%$ at the end. The TVB and lactobacilli count gradually increased from $\log 1.39 \mathrm{cfu} / \mathrm{ml}$ and $\log 1.04 \mathrm{cfu} / \mathrm{ml}$ respectively at the beginning to $\log 1.99 \mathrm{cfu} / \mathrm{ml}$ and $\log 1.95 \mathrm{cfu} / \mathrm{ml}$ respectively at the end. The fat, TS, acidity and $\mathrm{pH}$ of goat milk treated with gas decreased with the advancement of storage period, while protein, lactose, $\mathrm{SNF}$ and ash contents increased. For goat milk treated with charcoal, all chemical components increased towards the end of storage period except the acidity and $\mathrm{pH}$ which slightly decreased. When milk was treated with microwave, only fat content and $\mathrm{pH}$ decreased as storage period progressed and the other components steadily increased. For microbiological quality it was noticed that TVB and lactic acid bacteria counts increased drastically towards the end of storage period in milk treated with all heat sources, it 
Table 2. Effect of storage period on the physicochemical and microbiological characteristics of goat milk.

\begin{tabular}{|c|c|c|c|c|c|c|}
\hline \multirow{2}{*}{ Parameter } & \multicolumn{4}{|c|}{ Storage period (days) } & \multirow{2}{*}{ SE } & SL \\
\cline { 2 - 5 } & $\mathbf{1}$ & $\mathbf{3}$ & $\mathbf{7}$ & $\mathbf{1 0}$ & & \\
\hline Fat (\%) & $5.92^{\mathrm{a}}$ & $5.79^{\mathrm{a}}$ & $5.45^{\mathrm{a}}$ & $4.70^{\mathrm{b}}$ & 0.28 & $*$ \\
\hline Protein (\%) & $3.67^{\mathrm{b}}$ & $3.68^{\mathrm{b}}$ & $3.75^{\mathrm{ab}}$ & $3.80^{\mathrm{a}}$ & 0.05 & $*$ \\
\hline Total Solids (\%) & $14.09^{\mathrm{b}}$ & $15.01^{\mathrm{a}}$ & $15.70^{\mathrm{a}}$ & $15.68^{\mathrm{a}}$ & 0.47 & $*$ \\
\hline Lactose (\%) & $4.90^{\mathrm{b}}$ & $4.95^{\mathrm{b}}$ & $5.07^{\mathrm{b}}$ & $5.19^{\mathrm{a}}$ & 0.09 & $*$ \\
\hline Aolids-non-fat (\%) & $9.37^{\mathrm{b}}$ & $9.35^{\mathrm{b}}$ & $9.57^{\mathrm{b}}$ & $9.75^{\mathrm{a}}$ & 0.14 & $*$ \\
\hline Ash (\%) & $0.55^{\mathrm{b}}$ & $0.85^{\mathrm{a}}$ & $0.64^{\mathrm{ab}}$ & $0.61^{\mathrm{b}}$ & 0.02 & $* *$ \\
\hline Titratable acidity (\% lactic acid) & $0.21^{\mathrm{a}}$ & $0.23^{\mathrm{a}}$ & $0.24^{\mathrm{a}}$ & $0.26^{\mathrm{a}}$ & 0.14 & NS \\
\hline pH & $6.69^{\mathrm{a}}$ & $6.08^{\mathrm{b}}$ & $6.14^{\mathrm{b}}$ & $6.04^{\mathrm{b}}$ & 0.04 & $*$ \\
\hline Total bacterial count1 & $1.39^{\mathrm{d}}$ & $1.51^{\mathrm{c}}$ & $1.66^{\mathrm{b}}$ & $1.99^{\mathrm{a}}$ & 1.11 & $* * *$ \\
\hline Lactobacilli count1 & $1.04^{\mathrm{d}}$ & $1.66^{\mathrm{c}}$ & $1.71^{\mathrm{b}}$ & $1.95^{\mathrm{a}}$ & 1.19 & $* * *$ \\
\hline
\end{tabular}

Means in each row bearing similar superscripts are not significantly different $(\mathrm{P}>0.05)$

$$
\begin{gathered}
*=\mathrm{P}<0.05 \\
* *=\mathrm{P}<0.01 \\
* * *=\mathrm{P}<0.001
\end{gathered}
$$

NS $=$ Not significant

$\mathrm{SE}=$ Standard error of means

$\mathrm{SL}=$ Significance level

${ }^{1} \mathrm{Log} \mathrm{cfu} / \mathrm{ml}$

\begin{tabular}{|c|c|c|c|c|c|c|c|c|c|c|c|c|c|c|c|c|c|c|}
\hline \multirow{3}{*}{ Parameter } & \multicolumn{18}{|c|}{ Source of heat } \\
\hline & \multicolumn{6}{|c|}{ Gas } & \multicolumn{6}{|c|}{ Charcoal } & \multicolumn{6}{|c|}{ Microwave } \\
\hline & 1 & 3 & 7 & 10 & SL & SE & 1 & 3 & 7 & 10 & SL & SE & 1 & 3 & 7 & 10 & SL & SE \\
\hline Fat $(\%)$ & $3.69^{\mathrm{b}}$ & $3.05^{\mathrm{c}}$ & $3.83^{\mathrm{a}}$ & $3.07^{\mathrm{c}}$ & *** & 0.15 & $3.97^{\mathrm{b}}$ & $4.23^{a}$ & $4.19^{\mathrm{a}}$ & $3.52^{\mathrm{d}}$ & *** & 0.15 & $4.09^{\mathrm{a}}$ & $4.02^{\mathrm{a}}$ & $4.03^{a}$ & $3.56^{\mathrm{b}}$ & $*$ & 0.15 \\
\hline Protein $(\%)$ & $3.37^{\mathrm{ab}}$ & $3.19^{\mathrm{b}}$ & $3.51^{\mathrm{ab}}$ & $3.58^{a}$ & *** & 0.02 & $3.56^{\mathrm{ab}}$ & $3.60^{2}$ & $3.63^{\mathrm{a}}$ & $3.69^{a}$ & * & 0.02 & $3.52^{\mathrm{ab}}$ & $3.53^{\mathrm{ab}}$ & $3.53^{\mathrm{ab}}$ & $3.60^{2}$ & $*$ & 0.02 \\
\hline TS (\%) & $12.65^{\mathrm{d}}$ & $12.65^{\mathrm{d}}$ & $12.78^{\mathrm{cd}}$ & $12.81^{\mathrm{cd}}$ & *** & 0.56 & $12.81^{\mathrm{bcd}}$ & $13.15^{\text {bcd }}$ & $13.00^{\mathrm{bcd}}$ & $13.50^{\mathrm{bcd}}$ & NS & 0.56 & $12.86^{\mathrm{e}}$ & $15.30^{\mathrm{abc}}$ & $15.41^{\mathrm{ab}}$ & $16.50^{\mathrm{a}}$ & **** & 0.12 \\
\hline Lactose $(\%)$ & $4.81^{\mathrm{ab}}$ & $4.42^{\mathrm{b}}$ & $4.84^{\mathrm{ab}}$ & $4.97^{\mathrm{a}}$ & ** & 0.12 & $4.89^{\mathrm{a}}$ & $4.93^{\mathrm{a}}$ & $4.98^{a}$ & $5.10^{\mathrm{a}}$ & NS & 0.12 & $4.72^{\mathrm{ab}}$ & $4.74^{4 \mathrm{~b}}$ & $4.74^{\mathrm{ab}}$ & $4.91^{\mathrm{ab}}$ & NS & 0.56 \\
\hline SNF $(\%)$ & $8.99^{\mathrm{ab}}$ & $8.24^{\mathrm{b}}$ & $9.11^{\mathrm{ab}}$ & $9.26^{a}$ & $*$ & 0.2 & $9.15^{\mathrm{ab}}$ & $9.24^{\mathrm{a}}$ & $9.33^{\mathrm{a}}$ & $9.52^{\mathrm{a}}$ & $*$ & 0.2 & $8.93^{\mathrm{ab}}$ & $8.97^{\mathrm{ab}}$ & $8.95^{\mathrm{ab}}$ & $9.22^{\mathrm{a}}$ & $*$ & 0.2 \\
\hline Acidity1 & $0.20^{\mathrm{b}}$ & $0.23^{\mathrm{a}}$ & $0.16^{c}$ & $0.15^{\text {ef }}$ & $* * *$ & 0.01 & $0.18^{\text {bcde }}$ & $0.17^{\text {bcde }}$ & $0.14^{\mathrm{f}}$ & $0.17^{\text {bcde }}$ & $*$ & 0.01 & $0.16^{\mathrm{def}}$ & $0.19^{\mathrm{bcd}}$ & $0.17^{\mathrm{bcd}}$ & $0.19^{\mathrm{bc}}$ & $* * *$ & 0.01 \\
\hline Ash (\%) & $0.30^{c}$ & $0.48^{\mathrm{a}}$ & $0.50^{\mathrm{ab}}$ & $0.55^{\mathrm{ab}}$ & $* *$ & 0.01 & $0.44^{\mathrm{abc}}$ & $0.32^{\mathrm{bc}}$ & $0.57^{\mathrm{a}}$ & $0.53^{\mathrm{ab}}$ & $* * *$ & 0.01 & $0.46^{\mathrm{abc}}$ & $0.54^{\mathrm{ab}}$ & $0.48^{\mathrm{abc}}$ & $0.49^{\mathrm{abc}}$ & $*$ & 0.01 \\
\hline $\mathrm{pH}$ & $6.35^{\mathrm{a}}$ & $6.30^{\mathrm{a}}$ & $6.12^{\mathrm{a}}$ & $6.13^{\mathrm{a}}$ & NS & 0.04 & $6.48^{\mathrm{a}}$ & $6.30^{a}$ & $6.19^{a}$ & $6.13^{a}$ & NS & 0.04 & $6.46^{a}$ & $6.01^{\mathrm{a}}$ & $6.04^{a}$ & $6.00^{\mathrm{a}}$ & NS & 0.04 \\
\hline $\begin{array}{c}\text { TBC } \\
(\log 10)\end{array}$ & $1.93^{\mathrm{k}}$ & $2.03^{\mathrm{h}}$ & $2.30^{\mathrm{e}}$ & $2.62^{\mathrm{a}}$ & $* * *$ & 1.25 & $1.10^{\mathrm{i}}$ & $2.12^{\mathrm{g}}$ & $2.31^{\mathrm{d}}$ & $2.59^{\mathrm{b}}$ & $* * *$ & 1.19 & $1.90^{\mathrm{i}}$ & $2.03^{i}$ & $2.18^{\mathrm{f}}$ & $2.47^{\mathrm{c}}$ & *** & 1.19 \\
\hline $\begin{array}{c}\text { LAB } \\
(\log 10)\end{array}$ & $1.59^{\mathrm{i}}$ & $1.79^{\mathrm{i}}$ & $2.18^{f}$ & $2.65^{\mathrm{a}}$ & *** & 1.3 & $1.72^{\mathrm{i}}$ & $1.94^{\mathrm{g}}$ & $2.32^{\mathrm{d}}$ & $2.59^{\mathrm{b}}$ & *** & 1.24 & $1.55^{\mathrm{i}}$ & $1.83^{\mathrm{h}}$ & $2.30^{\mathrm{e}}$ & $2.54^{c}$ & *** & 1.24 \\
\hline
\end{tabular}

Table 3. Effect of storage period and method of heating on the physicochemical characteristics and microbiological quality of goats milk.

Means in each row bearing similar superscripts are not significantly different $(\mathrm{P}>0.05)$

$$
*=\mathrm{P}<0.05 ; \quad * *=\mathrm{P}<0.01 ; \quad * * *=\mathrm{P}<0.001 ; \quad \mathrm{NS}=\mathrm{Not} \text { significant }
$$

$\mathrm{SE}=$ Standard error of means

$\mathrm{SL}=$ Significance level

${ }^{1}$ expressed as $\%$ lactic acid

was also noticed that storage period adversely affected fat content of milk leading to decrease in value as the storage period progressed, while other components were not substantially affected. As the acidity fluctuated or decreased the $\mathrm{pH}$ also followed the same trend, and this contradicts the results of microbiological examination, since the increase in lactic acid bacteria should lead to reduction in the $\mathrm{pH}$ [21]. The results are in agreement with the findings of Hassan [19] for fat of UHT milk, and in disagreement with the results of protein, TS, and lactose contents. Villamiel et al. [22] reported the denaturatoin of whey protein by heating with microwave treatment. The increase in protein content during storage might have resulted in increased TS content together with increase in ash content. Hassan [19] observed no significant change in fat, protein, $\mathrm{SNF}$, acidity and $\mathrm{pH}$ of UHT treated milk during storage period of 12 weeks. Mohammed [23] found that total sol- ids content gradually increased from the beginning of storage, and then decreased at the end of storage period. The results of microbiological count agree with those reported by Hassan et al. [24] who reported an increasing total bacterial count of milk treated with UHT, low pasteurization $\left(85^{\circ} \mathrm{C} / 40 \mathrm{~min}\right)$ and high pasteurization $\left(98^{\circ} \mathrm{C} / 1.87 \mathrm{~min}\right)$ when stored for 30 days. However, the results in this study are in disagreement with Clare et al. [9] who found that microwave treatment eliminated all microbial growth, and that the sterility of milk was maintained through a 1-year storage period indicating an effective aseptic packaging method. In microwaved goat's milk, there was on average a 5-log reduction of the bacterial contamination of $106 \mathrm{cfu} / \mathrm{mL}$ [25]. Nakthong et al. [26] reported that all goat milk samples showed decrease in total microorganism count after the UV treatments, and during 20 days of storage, UV-treated milk samples also showed lower rates of 
microorganism growth than the untreated milk.

Identification of bacteria in goat milk heated by gas, charcoal and microwave

Bacteria were isolated post heat treatment and every 3 days of storage. The identification of bacteria isolated from milk is shown in Table 4. The following genera were isolated and identified: Staphylococcus and Bacillus. Our results agree with the findings of Burgess et al. [27] who concluded that, pasteurization does not destroy all pathogenic microorganisms, but reduce the number to a level at which they don't constitute a significant health hazards.
The importance of this research is that the use of gas and microwave does not affect the nutritive value of milk compared to charcoal, in addition to improving the microbiological quality of milk. Therefore, it is important that people in the Sudan use these methods for heat treatment of milk instead of charcoal which leads to removal of vegetation cover of the Sudan.

\section{Conclusion}

The significance of this study stems from the fact that in rural areas of Sudan the main method of milk heat treatment is charcoal, a practice which leads to the removal of vegetation by cutting the trees to be used in charcoal manufacture. Therefore, the

Table 4. Identification of bacteria in goat milk heated by gas, charcoal and microwave.

\begin{tabular}{|c|c|c|c|c|c|c|c|c|c|}
\hline Sample & Isolate & $\begin{array}{c}\text { Gram } \\
\text { Staining }\end{array}$ & Shape & $\begin{array}{c}\text { Endospore } \\
\text { staining }\end{array}$ & $\begin{array}{c}\text { Motility } \\
\text { test }\end{array}$ & $\begin{array}{c}\text { Catalase } \\
\text { test }\end{array}$ & $\begin{array}{c}\text { Oxidase } \\
\text { Test }\end{array}$ & $\begin{array}{l}\mathrm{O} / \mathrm{F} \\
\text { test }\end{array}$ & Genus \\
\hline Raw milk & 1 & + & Rod & - & + & + & - & $\mathrm{F}$ & Bacillus \\
\hline \multicolumn{10}{|c|}{ Day 1} \\
\hline Gas & 1 & + & Sphere & + & - & + & - & $\mathrm{F}$ & Staphylococcus \\
\hline Charcoal & 1 & + & Rod & + & + & + & - & $\mathrm{F}$ & Bacillus \\
\hline Microwave & 1 & + & Sphere & - & - & + & - & $\mathrm{F}$ & Staphylococcus \\
\hline \multicolumn{10}{|c|}{ Day 3} \\
\hline Gas & 1 & + & Rod & + & - & + & + & $\mathrm{F}$ & Bacillus \\
\hline Charcoal & 1 & + & Rod & + & + & + & - & $\mathrm{F}$ & Bacillus \\
\hline Microwave & 1 & + & Rod & - & + & - & + & OF & Bacillus \\
\hline \multicolumn{10}{|c|}{ Day 7} \\
\hline Gas & 1 & + & Sphere & - & - & + & - & $\mathrm{F}$ & Staphylococcus \\
\hline Charcoal & 1 & + & Rod & + & + & + & - & $\mathrm{F}$ & Bacillus \\
\hline Microwave & 1 & + & Sphere & - & + & - & - & $\mathrm{F}$ & Staphylococcus \\
\hline \multicolumn{10}{|c|}{ Day 10} \\
\hline Gas & 1 & + & Rod & + & + & + & - & $\mathrm{F}$ & Bacillus \\
\hline Charcoal & 1 & + & Rod & + & + & + & - & $\mathrm{F}$ & Bacillus \\
\hline Microwave & 1 & + & Rod & + & + & + & - & $\mathrm{F}$ & Bacillus \\
\hline
\end{tabular}

idea behind this study is to compare between charcoal, gas and microwave methods practically in order to convince the people in remote areas to use other methods to heat treat the milk without adversely affecting the environment.

\section{Acknowledgement}

The authors are grateful to the Ministry of Higher Education and Scientific Research for financial support.

\section{References}

[1]. Suguna M, Bhat R and Wan Nadiah WA (2012) Microbiological quality evaluation of goat milk collected from small-scale dairy farms in Penang Island, Malaysia. International Food Research Journal 19 (3): 1241-1245.

[2]. Raynal-Ljutovac, K, Massouras T and Barbosa M (2004) Goat milk and heat treatments. South African Journal of Animal Science 34 (Supplement 1): $173-175$.

[3]. Ozung PO, Nsa EE, Ebegbulem VN and Ubua J.A (2011) The potentials of small ruminant production in cross river rain forest zone of Nigeria: A review. Continental Journal of Animal and Veterinary Research 3 (1): 33 - 37.

[4]. Abdalla, MOM and Daffalla MS (2010) Comparison of chemical and microbiological parameters of charcoal versus gas and solar energy treated milk. Advance Journal of Food Science and Technology 2(5): 286-290.

[5]. Kordylas JM (1990) Processing and Preservation of Tropical and Subtropical Foods. CAB Direct 427 p.
[6]. Gedam K, Prasad R and Vijay VK (2007) The study on UHT processing of milk: A versatile option for rural sector. World Journal of Dairy Food Sciences 2(2): 49-53.

[7]. Reinemann DJ, Gouws P, Cilliers T, Houck K and Bishop JR (2006) New methods for UV treatment of milk for improved food safety and product quality. Proceedings of the American Society of Agricultural and Biological Engineers' Annual International Meeting; July 9-12; Portland, Oregon, USA.

[8]. Matak KE, Sumner SS, Duncan SE, Hovingh E, Worobo RW and Hackney CR (2007) Effects of ultraviolet irradiation on chemical and sensory properties of goat milk. Journal of Dairy Science 90 (7): 3178-3186.

[9]. Clare DA, Beng WS, Cartwright G, Darke MA, Coronel P and Simunovic J (2005) Comparison of sensory, microbiological and biochemical parameters of microwave versus indirect UHT fluid skim milk during storage. Journal of Dairy Science 88: 4172- 4182 .

[10]. Kyozaire JK, Vearya CM, Petzerb IM and Donkin EF (2005) Microbiological quality of goat's milk obtained under different production systems. Journal of South African Veterinary Association 76(2): 69-73.

[11]. Celestino EL, Iyer M and Roginski H (1997) Reconstituted UHT-treated milk-effects of raw-milk, powder quality and storage-conditions of UHT milk on its physicochemical attributes and flavor. International Dairy Journal 7(2-3):129-140

[12]. Boekel MAJS van and Walstra P (1989) Physical changes in the fat globules in unhomogenized and homogenized milk. Bulletin International Dairy Federation No. 238, Brussels, pp 13-16.

[13]. AOAC (2000) Association of Official Analytical Chemists. Methods of Analysis International, Gaitherburg, MD, USA.

[14]. Houghtby AG, Maturin LJ and Koenig KE (1992) "Microbiological Count Methods". Standard Methods for the Examination of Dairy Products $16^{\text {th }}$ 
Edn. RT Marshal (Ed). American Public Health Association, Washington D C pp 213-246.

[15]. Harrigan WF (1998) Laboratory Methods in Food Microbiology 3rd ed. Academic Press, London UK pp 202-245.

[16]. Barrow GI and Feltham RKA (1993) Cowan and Steel Manual for the identification of Medical Bacteria 3rd ed. Cambridge University Press, London, UK.

[17]. Bora K, Singh J and Goyal GK (1990) Changes in physico-chemical properties of goat milk due to boiling and simmering process. Indian Journal of Animal Sciences 60(1): 112- 114.

[18]. Sahan N, Konar A and Kleeberger A (1996) Effects of $\mathrm{H}_{2} \mathrm{O}_{2}$ addition and heat treatment on some physical chemical and microbial qualities of milk. Turkish Journal of Agriculture and Forestry 20: 1-7.

[19]. Hassan ABN (2008) Effect of heat treatment and storage conditions on the quality of cow milk. M.Sc. Thesis, University of Khartoum, Sudan.

[20]. Elzubeir EMI, Gabriechise V and Johnson Q (2007) Study on some quality control measures of pasteurized milk of the Western Cape, South Africa. International Journal of Dairy Science 2(4): 372-379.

[21]. Aggad H, Bridja M, Bouhai A, Benaouli M and Djebli A (2010) Some Quality Aspects of Pasteurized Milk in Algeria. World Journal of Dairy and Sciences 5(1): 21-24.
[22]. Villamiel M, Corzo N, Martinez-Castro I and Olano A (1996) Chemical changes during microwave treatment of milk. Food Chemistry 56(4): 385388.

[23]. Mohammed HMH (2006) Assessment of chemical and microbial quality of stirred yoghurt in Khartoum State, M .Sc. Thesis, University of Khartoum, Sudan.

[24]. Hassan ABN, Abdalla MOM and Nour MAA (2009) Microbiological quality of heat-treated milk during Storage. Pakistan Journal of Nutrition 8(12): 1845-1848.

[25]. Thompson JS and Thompson A (1990) In-home pasteurization of raw goat's milk by microwave treatment. International Journal of Food Microbiology 10 (1): 59-64.

[26]. Nakthong S, Boonlom J and Wichchukit S (2012) Using Ultraviolet Irradiation in Combination with Pasteurisation to Reduce Microorganism Content and Extend Shelf Life of Goat Milk. Proceedings of the First Asia Dairy Goat Conference; April 9-12; Kuala Lumpur, Malaysia.

[27]. Burgess K, Heggum C, Walker S and van Schothorst M (1994) Recommendations for the hygienic manufacture of milk and milk based products. Bulletin of the IDF No. 292, pp 32. 